\title{
Effect of different row spaces on yield and quality of Anise (Pimpinella anisum) under eskisehir ecological conditions
}

\author{
Nimet KATAR ${ }^{2}$, Duran KATAR *1 \\ ORCID: 0000-0003-0699-167X; 0000-0003-1340-8040
}

${ }^{1}$ Eskişehir Osmangazi University, Faculty of Agriculture, Department of Field Crops, Eskisehir, Turkey

${ }^{2}$ Eskisehir Directorate of Provincial Agriculture and Forestry, Eskisehir, Turkey

\begin{abstract}
To determine the effect of different row spaces on the yield, yield component and quality characteristics of Pimpinella anisum L., the field experiments were carried out in University of Eskisehir Osmangazi, Agricultural Faculty using randomized complete block design with three replications in 2017 and 2018. The row spaces used in the field experiments were 10,20,30,40,50 and $60 \mathrm{~cm}$. The effect of different row spaces on plant height $(\mathrm{cm})$, number of branches with umbels per plant, 1000 seed weight $(\mathrm{g})$, seed yield $\left(\mathrm{t} \mathrm{ha}^{-1}\right)$, essential oil content $(\%)$, essential oil yield (L $\mathrm{ha}^{-1}$ ) and essential oil composition of anise was determined in this study. Generally, increasing row spaces reduced the plant height while increasing number of branches with umbels per plant. The highest seed and essential oil yields were determined in $30 \mathrm{~cm}$ and $20 \mathrm{~cm}$ row spaces as $0.79 \mathrm{t} \mathrm{ha}^{-1}$ and $21.08 \mathrm{~L} \mathrm{ha}^{-1}$, respectively. Essential oil contents obtained from the experiment varied between $2.37 \%$ and $3.06 \%$, and it was observed that essential oil contents are above the $2 \%$ limit stated in the European pharmacopoeia. The anise essential oil samples were characterized by the occurrence of 17 various components, of which cuminaldehyde (33.745-37.098\%), p-cymene (14.643-16.865\%), $\gamma$-terpinene-7-al (10.590-13.407\%), $\gamma$-terpinene (9.587-11.986\%) and $\beta$-pinene (8.606-10.461\%) were the main components. When the results obtained from the experiment were evaluated, it was observed that the most appropriate row spacing for anise cultivation under Eskisehir Ecological condition was $30 \mathrm{~cm}$.
\end{abstract}

Key words: Anise (Pimpinella anisum L.), essential oil composition, quality, row spacing, yield

\section{Eskişehir ekolojik koşullarında farklı sıra aralıklarının Anason (Pimpinella anisum) verimi ve kalitesi üzerine} etkisi

\section{Özet}

Farklı sıra aralıklarının Pimpinella anisum L.'nin verim, verim komponentleri ve kalite özellikleri üzerindeki etkisini belirlemek için arazi çalışmaları, Eskişehir Osmangazi Üniversitesi Ziraat Fakültesi'nde 2017 ve 2018 yıllarında Tesadüf Blokları Deneme Desenine göre üç tekerrürlü olarak yürütülmüştür. Tarla denemelerinde kullanılan sıra aralıkları 10, 20, 30, 40, 50 ve $60 \mathrm{~cm}$ 'dir. Bu çalışmada, farklı sıra aralıklarının anasonun bitki boyu (cm), bitki başına şemsiyeli dal sayısı, 1000 tohum ağırlığı $(\mathrm{g})$, tohum verimi $\left(\mathrm{t} \mathrm{ha}^{-1}\right)$, uçucu yağ oranı $(\%)$, uçucu yağ verimi $\left(\mathrm{L} \mathrm{L}^{-1}\right)$ ve uçucu yağ kompozisyonu belirlenmiştir. Genel olarak, artan sıra aralıkları bitki başına şemsiyeli dal sayısını artırırken, bitki boyunu azaltmıştır. En yüksek tohum ve uçucu yağ verimleri $30 \mathrm{~cm}$ ve $20 \mathrm{~cm}$ sıra aralıklarından sırasıyla $0.79 \mathrm{t}$ ha' ${ }^{1}$ ve $21.08 \mathrm{~L} \mathrm{ha}^{-1}$ olarak belirlenmiştir. Çalışmadan elde edilen uçucu yă oranları \% 2.37 ile \% 3.06 arasında değişmekte olup, uçucu yağ oranlarının Avrupa farmakopesinde belirtilen \% 2 sınırının üzerinde olduğu görülmüştür. Anason uçucu yağ örneklerinde 17 farklı komponent tespit edilmiş olup, ana komponentler cuminaldehit (\% 33.74537.098), p-cymene (\% 14.643-16.865), $\gamma$-terpinen-7-al (\% 10.590-13.407), $\gamma$-terpinen (\% 9.587-11.986) ve $\beta$-pinen (\%

\footnotetext{
${ }^{*}$ Corresponding author / Haberleşmeden sorumlu yazar: Tel.: +902222393750; Fax.: +902223242990; E-mail: durankatar6060@ gmail.com

(C) Copyright 2020 by Biological Diversity and Conservation $\quad$ Received: xx.xx.2020; Published: 15.12.2020 $\quad$ BioDiCon. 913-0820
} 
8.606-10.461)'dir. Çalışmadan elde edilen sonuçlar değerlendirildiğinde, Eskişehir Ekolojik koşulları altında anason yetiştiriciliği için en uygun sıra aralığının $30 \mathrm{~cm}$ olduğu gözlenmiştir.

Anahtar kelimeler: Anason (Pimpinella anisum L.), uçucu yağ kompozisyonu, kalite, sıra arası mesafe, verim

\section{Introduction}

Anise (Pimpinella anisum L.), belonging to the Umbelliferae (Apiaceae) family with around 300 genera and 3000 species, is an annual aromatic herb [1,2]. Anise is a plant with natural distribution in the Mediterranean basin and Southwest Asia [1, 3]. It is an herbaceous plant with a height of about $90 \mathrm{~cm}$. The leaves on the lower part of the stem are simple, 1.3-5.1 cm long and shallow lobed, while the leaves on the upper part of the stem are hairy pinnate and divided into numerous leaflets. The plant with umbellate inflorescences has flowers with approximately $3 \mathrm{~mm}$ in diameter and white in color. Schizocarp fruits are 3-5 mm long [1, 4].

Plants have been the source of many medicines used in the treatment of both humans and animals since ancient times. This showed that throughout history, people's relationship with plants has been not only about using them as a source of food, but also as a source of medicine. Many scientific studies in recent years have shown that there were many plant species used as a source of medicine. One of these plants used for medicinal purposes was anise (Pimpinella anisum L.) belonging to the Umbelliferae family. The plant has been used in the folk medicine of many countries (especially the fruits of the plant) as carminative, gastric protection, aromatic, disinfectant and galactagogue. To date, numerous different scientific studies have been conducted on anise seeds and have been reported to have antimicrobial, antifungal, antiviral, antioxidant, muscle relaxant, painkiller and anti-spasmodic effects as well as different effects on the digestive system $[3,5]$. Today, anise is an important raw material used in pharmacy, perfumery, food and cosmetic industries [1]. It also has the effect of reducing of morphinism and is effective against menstrual pain in women and high fever in menopausal women. For diabetics, anise seeds not only decrease glucose value and lipid level in blood but also decrease lipid peroxidation [5]. In addition, anise is used to impart flavor and aroma to different products such as seafood, ice cream, desserts and chewing gum in the food industry [3]. Anise essential oil and its tea are used as a natural asthma medication as well as being used to relieve the shortness of breath in aromatherapy. Also, anise essential oil is used in the treatment of itching caused by lice and other insects, as well as to eliminate head and body lice. Ointments derived from the essential oil of the plant are used externally in the treatment of scabies [1].

The quality of the anise seed is determined by the proportion of the essential oil and the composition of the essential oil [1]. The composition of the anise seed varies significantly depending on the origin and cultivation method. These values for anise seed were as follows; moisture: 9-13\%, protein: 18\%, oil ratio: $8-23 \%$, essential oil: $1.5-7.0 \%$ (on average around 2-3\%), starch: 5\%, N-free extract: 22-28\%, crude fiber: $12-25 \%$ [2, 3]. According to European pharmacopoeia, anise seeds to be used as medicines must contain at least $2 \%$ of essential oil [1]. The most important compounds of the essential oil that make up $1.5-7 \%$ of the anise seed were trans-anethol, estragolle, $\gamma$-hymachalene, paraanisaldehyde and methyl cavicol $[4,5,6]$. Some studies showed that the most important compound of anise essential oil, trans-anetholhe, constituted $80-90 \%$ of essential oil [1, 3].

In cultivated plants, optimum plant density varies widely depending on the environment conditions, agronomic practices and cultivars used. The optimum number of plants in the unit area and the uniform distribution of these plants are of great importance in obtaining sufficient yield and high quality products. Row spacing is one of the important factors affecting the yield and quality of medicinal aromatic plants [7]. Scientific studies had shown that the content and chemical composition of the essential oil of medicinal and aromatic plants was influenced by a number of factors such as genetic, ontogenetic and environmental factors, as well as agronomic (plant density, fertilization, irrigation, cultivation and harvesting methods) applications $[8,9,10]$.

The aim of this study was to determine the most suitable row spacing for anise cultivation under Eskisehir ecological conditions.

\section{Materials and Methods}

The study was carried out at the experimental fields of Eskisehir Osmangazi University Agricultural Faculty during crop growing period of 2017 and 2018. The plant material used in the experiment was obtained from a farmer cultivating anise in Burdur province. The plant material containing plants with different genetic makeup was not cultivar and had a population characteristic. The properties of the experimental soils were given in Table 1. Soil characteristics in 2017 and 2018 were: loamy, $\mathrm{pH} 7.18$ and 7.53 , lime $5.55 \%$ and $5.32 \%$, salt $0.035 \mathrm{ds} \mathrm{m}^{-1}$ and $0.042 \mathrm{ds}$ $\mathrm{m}^{-1}$, organic matter $2.43 \%$ and $2.82 \%$, phosphorus $59.6 \mathrm{~kg} \mathrm{ha}^{-1}$ and $66.1 \mathrm{~kg} \mathrm{ha}^{-1}$ and potassium $1952.8 \mathrm{~kg} \mathrm{ha}^{-1}$ and $2482.7 \mathrm{~kg} \mathrm{ha}^{-1}$. There are no restrictions on the growth of the anise plant in the soil of the experiment area. 
Table 1. Some physical and chemical properties of soils in experimental fields*

\begin{tabular}{|c|c|c|c|c|c|c|}
\hline Structure & $\begin{array}{l}\text { Lime } \\
(\%)\end{array}$ & $\begin{array}{l}\text { Salt } \\
\left(\text { ds } \mathbf{~ m}^{-1}\right)\end{array}$ & $\begin{array}{l}\text { Available } \\
\text { Phosphorus } \\
\left(\mathbf{P}_{2} \mathrm{O}_{5}\right)\left(\mathrm{kg} \mathrm{ha}^{-1}\right)\end{array}$ & $\begin{array}{l}\text { Available } \\
\text { Potassium } \\
\left.\left(\mathrm{K}_{2} \mathrm{O}\right)\left(\mathrm{kg} \mathrm{ha}^{-1}\right)\right)\end{array}$ & pH & $\begin{array}{l}\text { Organic } \\
\text { Matter } \\
(\%)\end{array}$ \\
\hline Loamy (2017) & 5.55 & 0.035 & 59.6 & 1952.8 & 7.18 & 2.43 \\
\hline Loamy (2018) & 5.32 & 0.042 & 66.1 & 2482.7 & 7.53 & 2.82 \\
\hline
\end{tabular}

*Soil analyze was carried out in Transitıonal Zone Agricultural Research Institute Soil-Plant-Water analysis and Physiology laboratories

Mean temperature and total precipitation data were presented in Table 2. Total annual precipitation in longterm period was $338.8 \mathrm{~mm}$, whereas this value was higher both in 2017 (374.4 mm) and in 2018 (411.8 mm). Also, the mean temperature for long-term period was lower than the mean temperature values for both 2017 and 2018 . Mean temperature in 2017 and 2018 were $11.29^{\circ} \mathrm{C}$ and $12.50^{\circ} \mathrm{C}$, respectively.

Table 2. Meteorological data of the experiment years*

\begin{tabular}{|c|c|c|c|c|c|c|}
\hline \multirow{2}{*}{ Months } & \multicolumn{3}{|c|}{ Total Precipitation $(\mathrm{mm})$} & \multicolumn{3}{|c|}{ Mean Temperature $\left({ }^{\circ} \mathrm{C}\right)$} \\
\hline & 2017 & 2018 & LYA $* *$ & 2017 & 2018 & LYA $* *$ \\
\hline January & 33.00 & 30.00 & 30.6 & -2.00 & 1.40 & -0.2 \\
\hline February & 9.20 & 28.80 & 26.1 & 1.90 & 5.60 & 0.9 \\
\hline March & 16.20 & 49.80 & 27.6 & 7.60 & 8.90 & 4.9 \\
\hline April & 62.00 & 16.80 & 43.1 & 9.60 & 13.60 & 9.6 \\
\hline May & 50.80 & 72.00 & 40.0 & 14.40 & 16.40 & 14.9 \\
\hline June & 44.80 & 60.60 & 23.7 & 19.10 & 19.30 & 19.1 \\
\hline July & 13.40 & 42.00 & 13.1 & 23.10 & 21.90 & 22.1 \\
\hline August & 31.40 & 19.30 & 9.2 & 22.00 & 22.70 & 21.8 \\
\hline September & 3.00 & 3.80 & 18.1 & 19.60 & 18.30 & 16.7 \\
\hline October & 46.60 & 30.10 & 32.8 & 10.80 & 13.00 & 11.7 \\
\hline November & 27.80 & 18.60 & 34.0 & 5.50 & 7.40 & 5.6 \\
\hline December & 36.20 & 40.00 & 40.5 & 3.90 & 1.7 & 1.7 \\
\hline Total/Mean & 374.40 & 411.80 & 338.8 & 11.29 & 12.50 & 10.7 \\
\hline
\end{tabular}

*Eskisehir Regional Meteorological Service; ** Long Year Mean

The experimental design was a randomized complete block design with three replications. Seeds were sown by hand, with different row spaces $(10,20,30,40,50$ and $60 \mathrm{~cm})$ at 2-3 cm depth on 15 April of 2017 and 23 April of 2018. Seeding was performed with a sowing rate of $20 \mathrm{~kg} \mathrm{ha}^{-1}$.

Each plot length was $5 \mathrm{~m}$ and consisted of 6 rows [11]. Weed control was made by hand when needed. No irrigation was applied. The experimental plots were fertilized with a dose of $50 \mathrm{~kg} \mathrm{~N}$ and $40 \mathrm{~kg} \mathrm{P}_{2} \mathrm{O}_{5}$ per ha. A row was removed from both sides of the plots as side effect and then the plants in the plots were harvested by hand on 9 July 2017 and 12 July 2018.

In order to determine the essential oil content, $100 \mathrm{~g}$ drug seed samples in 1.0 I water from each sample were extracted by hydro-distillation for 3 hours using Clevenger apparatus according to the standard procedure described in European Pharmacopoeia [12] for determining the oil content (v/w, \%). Samples of essential oil obtained by water distillation were stored in refrigerator at $4{ }^{\circ} \mathrm{C}$ until the composition analysis.

The essential oil compositions of the oil samples were analyzed by gas chromatography (Agilent 5975C) coupled to mass spectrometry (Agilent 5975C) using capillary column (HP Innowax Capillary; $60.0 \mathrm{~m} \mathrm{x} 0.25 \mathrm{~mm} \times$ $0.25 \mu \mathrm{m}$ ). Helium was used as carrier gas at $0,8 \mathrm{ml} \mathrm{min}^{-1}$ flow rate. Essential oils were diluted 1:100 ratios with hexane to analyze its composition. GC-MS analysis was carried out at split mode (40:1). The samples injection volume was adjusted as $1 \mu \mathrm{l}$ and injection temperature as $250{ }^{\circ} \mathrm{C}$. The oven temperature was programmed as $60^{\circ} \mathrm{C}$ for 10 minutes, increased at $4^{\circ} \mathrm{C}$ per minute to $220^{\circ} \mathrm{C}$, and held at $220^{\circ} \mathrm{C}$ for 10 minutes. MS spectra were monitored between $35-450$ amu and the ionization mode used was electronic impact at $70 \mathrm{eV}$. The relative percentage of the components was calculated from GC-MS peak areas and components were identified by WILEY, and OIL ADAMS libraries. The percentage ratios of the results were determined by using FID detector, the identification of the components were determined by using MS detector.

The results obtained from the field experiments were subjected to analysis of variance using SPSS statistical software program, and differences between mean values were compared via the Tukey (Tukey's Honest Significant Difference test) test. 


\section{Results and Discussion}

As with other cultivated plants, the yield and quality of the product to be obtained in medicinal aromatic plants results from the interaction of the genetic makeup of the plant material with the ecological conditions of the region and agronomic applications $[13,14,15,16,17,18]$. For this reason, it is of great importance to determine the most appropriate agronomic applications by the researches that will be carried out in order to produce high yield and quality products in a region.

Plant height is mainly controlled by the genetic structure of the plant material. However, it can also be affected by environmental factors and agronomic applications [13]. Years and different row spaces had a significant impact on plant height values. However, row spaces x year interaction has not had a significant effect on this parameter. The higher plant height value $(48.89 \mathrm{~cm})$ was obtained in 2018 compared to the mean value $(46.77 \mathrm{~cm})$ obtained in 2017. Compared with row spaces according to the mean value of two-year, the highest plant heights (53.93 and 52.17 $\mathrm{cm}$ ) were counted in 10 and $20 \mathrm{~cm}$ row spaces, respectively. In general, a decrease in plant height values was detected due to increasing row spacing (Table 3). This can be explained by the increased light competition between plants depending on the decreasing row spacing [19].

Table 3. The effects of years and row spacing factors on mean values of yield components of anise

\begin{tabular}{|c|c|c|c|c|c|c|}
\hline \multirow{2}{*}{$\begin{array}{l}\text { Row spaces } \\
(\mathbf{c m})\end{array}$} & \multicolumn{3}{|c|}{$\begin{array}{l}\text { Plant Height } \\
(\mathrm{cm})\end{array}$} & \multicolumn{3}{|c|}{$\begin{array}{l}\text { Number of branches with } \\
\text { umbels per plant }\end{array}$} \\
\hline & 2017 & 2018 & Mean & 2017 & 2018 & Mean \\
\hline 10 & 52.23 & 55.62 & $53.93 \mathrm{a}$ & 3.09 & 3.24 & $3.16 \mathrm{~d}$ \\
\hline 20 & 50.93 & 53.41 & $52.17 \mathrm{ab}$ & 4.12 & 4.33 & $4.22 \mathrm{c}$ \\
\hline 30 & 48.60 & 50.09 & $49.35 \mathrm{bc}$ & 4.99 & 5.27 & $5.13 \mathrm{~b}$ \\
\hline 40 & 47.07 & 49.42 & $48.24 \mathrm{c}$ & 5.72 & 6.09 & $5.90 \mathrm{a}$ \\
\hline 50 & 43.90 & 45.70 & $44.80 \mathrm{~d}$ & 6.19 & 6.38 & $6.28 \mathrm{a}$ \\
\hline 60 & 37.90 & 39.13 & $38.51 \mathrm{e}$ & 6.35 & 6.50 & $6.43 \mathrm{a}$ \\
\hline Mean & $46.77 \mathrm{~B}$ & $48.89 \mathrm{~A}$ & 47.83 & $5.08 \mathrm{~B}$ & $5.30 \mathrm{~A}$ & 5.19 \\
\hline$F$ value & \multicolumn{3}{|c|}{$\begin{array}{l}\text { Year: 453.586**; Row space: } 58.510 * * ; \\
\text { Year x Row space: } 0.291 \mathrm{~ns}\end{array}$} & \multicolumn{3}{|c|}{$\begin{array}{l}\text { Year: 51.435*; Row space: } 116.717 * * \\
\text { Year x Row space: } 0.126 \mathrm{~ns}\end{array}$} \\
\hline $\mathrm{CV}(\%)$ & \multicolumn{3}{|c|}{11.37} & \multicolumn{3}{|c|}{23.84} \\
\hline \multirow{2}{*}{$\begin{array}{l}\text { Row spaces } \\
(\mathrm{cm})\end{array}$} & \multicolumn{3}{|c|}{1000 seed weight (g) } & \multicolumn{3}{|c|}{ Seed yield $\left(t\right.$ ha $\left.^{-1}\right)$} \\
\hline & 2017 & 2018 & Mean & 2017 & 2018 & Mean \\
\hline 10 & 3.43 & 3.77 & 3.60 & 0.33 & 0.36 & $0.35 \mathrm{c}$ \\
\hline 20 & 3.50 & 3.72 & 3.61 & 0.72 & 0.76 & $0.74 \mathrm{a}$ \\
\hline 30 & 3.32 & 3.63 & 3.47 & 0.76 & 0.82 & $0.79 \mathrm{a}$ \\
\hline 40 & 3.03 & 3.32 & 3.17 & 0.50 & 0.56 & $0.53 \mathrm{~b}$ \\
\hline 50 & 3.12 & 3.42 & 3.27 & 0.28 & 0.29 & $0.28 \mathrm{~cd}$ \\
\hline 60 & 3.48 & 3.65 & 3.56 & 0.20 & 0.21 & $0.20 \mathrm{~d}$ \\
\hline Mean & $3.31 \mathrm{~B}$ & $3.58 \mathrm{~A}$ & 3.45 & $0.46 \mathrm{~B}$ & $0.50 \mathrm{~A}$ & 0.48 \\
\hline F value & \multicolumn{3}{|c|}{$\begin{array}{l}\text { Year: 62.736*; Row space: } 1.495 \mathrm{od} \text {; Year } \\
\text { x Row space: } 0.045 \mathrm{~ns}\end{array}$} & \multicolumn{3}{|c|}{$\begin{array}{l}\text { Year: } 183.211 * * ; \text { Row space: } 140.498 * * ; \\
\text { Year x Row space: } 0.208 \mathrm{~ns}\end{array}$} \\
\hline $\mathrm{CV}(\%)$ & \multicolumn{3}{|c|}{11.72} & \multicolumn{3}{|c|}{47.73} \\
\hline \multirow{2}{*}{$\begin{array}{l}\text { Row space } \\
(\mathrm{cm})\end{array}$} & \multicolumn{3}{|c|}{ Essential oil content (\%) } & \multicolumn{3}{|c|}{ Essential oil yield $\left(\mathrm{L} \mathrm{ha}^{-1}\right)$} \\
\hline & 2017 & 2018 & Mean & 2017 & 2018 & Mean \\
\hline 10 & 2.40 & 2.73 & $2.57 \mathrm{bc}$ & 8.05 & 9.83 & $8.94 \mathrm{c}$ \\
\hline 20 & 2.77 & 2.96 & $2.87 \mathrm{ab}$ & 19.73 & 22.43 & $21.08 \mathrm{a}$ \\
\hline 30 & 2.37 & 2.58 & $2.48 \mathrm{c}$ & 18.04 & 21.14 & $19.59 \mathrm{a}$ \\
\hline 40 & 2.70 & 2.91 & $2.81 \mathrm{ab}$ & 13.57 & 16.28 & $14.93 \mathrm{~b}$ \\
\hline 50 & 2.83 & 2.96 & $2.90 \mathrm{a}$ & 7.84 & 8.58 & $8.21 \mathrm{~cd}$ \\
\hline 60 & 2.73 & 3.06 & $2.90 \mathrm{a}$ & 5.34 & 6.48 & $5.91 \mathrm{~d}$ \\
\hline Mean & $2.63 \mathrm{~B}$ & $2.87 \mathrm{~A}$ & 2.75 & $12.09 \mathrm{~B}$ & $14.12 \mathrm{~A}$ & 13.11 \\
\hline F value & \multicolumn{3}{|c|}{$\begin{array}{l}\text { Year : 46.661*; Row space: } 6.890^{* *} \text {; Year } \\
\text { x Row space: } 0.319 \mathrm{~ns}\end{array}$} & \multicolumn{3}{|c|}{$\begin{array}{l}\text { Year: 93.061*; Row space: } 119.670^{* *} \text {; } \\
\text { Year x Row space: } 0.680 \mathrm{~ns}\end{array}$} \\
\hline CV $(\%)$ & \multicolumn{3}{|c|}{9.20} & \multicolumn{3}{|c|}{46.46} \\
\hline
\end{tabular}

The years and row spaces had a significant impact on the number of branches with umbels per plant and a higher value (5.30) was determined in 2018 compared to 2017 (5.08). As the mean of two-year, the number of branches 
with umbels per plant ranged from 3.16 to 6.43 and the highest value was determined in $60 \mathrm{~cm}$ row space. However, 40, 50 and $60 \mathrm{~cm}$ row spacings were statistically in same post-hoc group (Table 3). Our findings in this parameter can be explained by the increase in the space between the rows for the plants depending on the increasing row spacing. Because the increasing gap between rows had an encouraging effect on branching in plants.

Only a significant difference between years was detected in terms of 1000 seed weight. As the mean of row spaces, the 1000 seed weight was $3.31 \mathrm{~g}$ in 2017 and $3.58 \mathrm{~g}$ in 2018 (Table 3). The 1000 seed weight values obtained from the study showed us that the changing row spacing did not have a significant effect on this parameter.

The years and row spaces had a significant effect on seed yield $\left(\mathrm{t} \mathrm{ha}^{-1}\right)$. While mean seed yield was $0.46 \mathrm{tha}^{-1}$ in 2017, It was $0.50 \mathrm{t} \mathrm{ha}^{-1}$ in 2018. According to the mean of two-year, the seed yield ranged from 0.20 to $0.79 \mathrm{t} \mathrm{ha}^{-1} \mathrm{and}$ the highest value was determined in $30 \mathrm{~cm}$ row space. However, in terms of seed yield, there was no statistically significant difference between $20 \mathrm{~cm}$ and $30 \mathrm{~cm}$ row space (Table 3). These results are in agreement with those obtained by [26].

Table 4. The effect of different row spaces on essential oil composition of anise

\begin{tabular}{lllllllll}
\hline $\begin{array}{l}\text { Row spaces } \\
\mathbf{1 0} \mathbf{~ c m}\end{array}$ & & & $\mathbf{2 0} \mathbf{~ c m}$ & & & $\mathbf{3 0} \mathbf{c m}$ & \\
R.T. & Composition & $\mathbf{\%}$ & $\mathbf{R . T}$ & Composition & $\mathbf{\%}$ & $\mathbf{R . T}$. & Composition & \% \\
\hline 11.10 & $\alpha$-Pinene & 0.55 & 11.10 & $\alpha$-Pinene & 0.41 & 11.10 & $\alpha$-Pinene & 0.48 \\
14.46 & $\beta$-Pinene & 10.46 & 14.46 & $\beta$-Pinene & 8.61 & 14.46 & $\beta$-Pinene & 9.53 \\
15.03 & Sabinene & 0.48 & 15.03 & Sabinene & 0.40 & 15.03 & Sabinene & 0.44 \\
16.83 & $\beta$-Myrcene & 0.74 & 16.83 & $\beta$-Myrcene & 0.61 & 16.83 & $\beta$-Myrcene & 0.67 \\
16.98 & $\alpha$-Phellandrene & 2.85 & 16.98 & $\alpha$-Phellandrene & 2.44 & 16.98 & $\alpha$-Phellandrene & 2.65 \\
18.47 & Limonene & 0.70 & 18.47 & Limonene & 0.66 & 18.47 & Limonene & 0.68 \\
18.92 & $\beta$-Phellandrene & 0.76 & 18.92 & $\beta$-Phellandrene & 0.68 & 18.92 & $\beta$-Phellandrene & 0.72 \\
20.48 & $\gamma$-Terpinene & 11.99 & 20.47 & $\gamma$-Terpinene & 9.59 & 20.47 & $\gamma$-Terpinene & 10.79 \\
21.57 & p-Cymene & 16.87 & 21.57 & p-Cymene & 14.64 & 21.57 & p-Cymene & 15.75 \\
32.67 & $\beta$-Cyclocitral & 1.19 & 32.67 & $\beta$-Cyclocitral & 1.07 & 32.67 & $\beta$-Cyclocitral & 1.13 \\
36.38 & $\beta$-Acoradiene & 0.41 & 36.38 & $\beta$-Acoradiene & 0.35 & 36.38 & $\beta$-Acoradiene & 0.38 \\
39.12 & Cuminaldehyde & 37.10 & 39.11 & Cuminaldehyde & 33.75 & 39.11 & Cuminaldehyde & 35.34 \\
39.53 & $\gamma$-Terpinene-7-al & 10.59 & 39.53 & $\gamma$-Terpinene-7-al & 12.86 & 39.53 & $\gamma$-Terpinene-7-al & 13.22 \\
40.20 & Anethole & 1.69 & 40.19 & Anethole & 10.85 & 40.19 & Anethole & 6.27 \\
45.21 & Carotol & 0.54 & 45.21 & Carotol & 0.43 & 45.21 & Carotol & 0.48 \\
46.84 & Cumin alcohol & 0.47 & 46.84 & Cumin alcohol & 0.44 & 46.84 & Cumin alcohol & 0.46 \\
49.26 & Carvacrol & 0.52 & 49.25 & Carvacrol & 0.45 & 49.25 & Carvacrol & 0.49 \\
\hline Unidentified & & 2.11 & & 1.78 & & & 98.53 \\
Total & & & 97.8 & & & & 99.4 \\
\hline
\end{tabular}

The most important quality criterion of anise plant, which is an important aromatic plant, is the essential oil content. Because the essential oil rate is of great importance together with the composition of the essential oil in determining the market price of anise product. Industry, which uses anise as raw material, wants the desired product to have an essential oil ratio over a certain value. According to the European pharmacopoeia, this rate should contain at least $2 \%$ essential oil for the anise seeds to be used as medicines [1]. It was determined that all the essential oil ratio values obtained in this study were above the $2 \%$ level stated in the European pharmacopoeia. According to the mean of two-year, the essential oil content values ranged from 2.48 to $2.90 \%$ and the highest value was determined in 50 and 60 $\mathrm{cm}$ row spaces. Although the essential oil contents obtained from 20 and $40 \mathrm{~cm}$ row spaces were slightly lower than the values taken from 50 and $60 \mathrm{~cm}$ row spaces. The essential oil contents in 2017 and 2018 were determined as $2.63 \%$ and $2.87 \%$, respectively (Table 3). Plant density, an important agronomic practice, affects the essential oil content by changing the micro ecological conditions present for each plant [20,21]. Our findings for the essential oil content are in line with the others reported by [2], [3] and [6].

Years and row space had significant effects ( $\mathrm{P}<0.05$ and $\mathrm{P}<0.01$, respectively) on essential oil yield. The essential oil yield value $\left(14.12 \mathrm{~L} \mathrm{ha}^{-1}\right)$ obtained in 2018 was higher than the data $\left(12.09 \mathrm{~L} \mathrm{ha}^{-1}\right)$ of 2017 . According to the mean of two-year, the essential oil yield ranged from 5.91 to $21.08 \mathrm{~L} \mathrm{ha}^{-1}$ and the highest value was determined in $20 \mathrm{~cm}$ row space that is in the same group with $30 \mathrm{~cm}$ row space (Table 3 ).

Results indicated that the effect of years was significant on plant height $(\mathrm{cm})$, number of branches with umbels per plant, 1000 seed weight $(\mathrm{g})$, seed yield $\left(\mathrm{t} \mathrm{ha}^{-1}\right)$, essential oil content $(\%)$, essential oil yield $\left(\mathrm{L} \mathrm{ha}^{-1}\right)$. This can be explained by the fact that climate factors such as precipitation, temperature and solar radiation change from year to year. Because changing climate conditions affecting plant growth and development determine the yield and quality of the product $[15,22]$. In addition, the effect of row spacing was found to be significant on plant height (cm), number of branches with umbels per plant, seed yield $\left(\mathrm{t} \mathrm{ha}^{-1}\right)$, essential oil content $(\%)$, essential oil yield $\left(\mathrm{L} \mathrm{ha}^{-1}\right)$. This can be attributed to the change in plant microclimates due to varying row spacing $[23,24]$. In the study, the sowing rate of 20 
$\mathrm{kg} \mathrm{ha}^{-1}$ did not change. For this reason, increasing inter-row spaces increased the density of the plants on the row. Excessive density occurring in the plants on the row affects the yield and quality negatively by increasing the competition between plants. Inadequate plant density, on the other hand, affects the yield negatively since it prevents obtaining sufficient plant stands. The highest yield and quality can be obtained from the plant density, which provides the most suitable growth and development environment for each plant.

The peculiar smell and aroma therapeutic properties of each essential oil vary depending on the components of the essential oil and the ratio of these compounds in the essential oil [25]. Therefore, knowing the composition of essential oils is of great importance to determine the commercial value and using area of the essential oil.

In this experiment, the anise essential oils were characterized by the occurrence of 17 various components, of which cuminaldehyde (33.745-37.098\%), p-cymene (14.643-16.865\%), $\gamma$-terpinene-7-al (10.590-13.407\%), $\gamma$-terpinene (9.587-11.986\%) and $\beta$-pinene (8.606-10.461) were the main components. In anise essential oil, the main components made up 79.438-87.00\% of the total essential oil. The content of cuminaldehyde, which was found to be the highest component in anise essential oil, was observed to change by $9.34 \%$ depending on the changing row spaces. Similarly, depending on the changing row spaces, the changes in p-cymene, $\gamma$-terpinene-7-al, $\gamma$-terpinene and $\beta$-pinene ratios were determined as $15.17 \%, 26.60 \%, 25.02 \%$ and $21.55 \%$, respectively (Table 4 ).

Table 4. continued

\begin{tabular}{|c|c|c|c|c|c|c|c|c|}
\hline \multicolumn{9}{|c|}{ Row spaces } \\
\hline \multicolumn{3}{|c|}{$40 \mathrm{~cm}$} & \multicolumn{3}{|l|}{$50 \mathrm{~cm}$} & \multicolumn{3}{|l|}{$60 \mathrm{~cm}$} \\
\hline R.T. & Composition & $\%$ & R.T. & Composition & $\%$ & R.T. & Composition & $\%$ \\
\hline 11.11 & $\alpha$-Pinene & 0.51 & 11.11 & $\alpha$-Pinene & 0.44 & 11.11 & $\alpha$-Pinene & 0.47 \\
\hline 14.47 & $\beta$-Pinene & 10.00 & 14.46 & $\beta$-Pinene & 9.07 & 14.46 & $\beta$-Pinene & 9.53 \\
\hline 15.04 & Sabinene & 0.46 & 15.03 & Sabinene & 0.42 & 15.03 & Sabinene & 0.43 \\
\hline 16.84 & $\beta$-Myrcene & 0.71 & 16.84 & $\beta$-Myrcene & 0.64 & 16.84 & $\beta$-Myrcene & 0.67 \\
\hline 16.98 & $\alpha$-Phellandrene & 2.75 & 16.98 & $\alpha$-Phellandrene & 2.54 & 16.98 & $\alpha$-Phellandrene & 2.64 \\
\hline 18.48 & Limonene & 0.69 & 18.47 & Limonene & 0.67 & 18.47 & Limonene & 0.67 \\
\hline 18.93 & $\beta$-Phellandrene & 0.74 & 18.92 & $\beta$-Phellandrene & 0.70 & 18.92 & $\beta$-Phellandrene & 0.71 \\
\hline 20.48 & $\gamma$-Terpinene & 11.39 & 20.47 & $\gamma$-Terpinene & 10.19 & 20.47 & $\gamma$-Terpinene & 10.78 \\
\hline 21.57 & p-Cymene & 16.31 & 21.57 & p-Cymene & 15.20 & 21.57 & p-Cymene & 15.75 \\
\hline 32.68 & $\beta$-Cyclocitral & 1.16 & 32.67 & $\beta$-Cyclocitral & 1.10 & 32.67 & $\beta$-Cyclocitral & 1.12 \\
\hline 36.39 & $\beta$-Acoradiene & 0.39 & 36.38 & $\beta$-Acoradiene & 0.37 & 36.38 & $\beta$-Acoradiene & 0.38 \\
\hline 39.12 & Cuminaldehyde & 35.63 & 39.12 & Cuminaldehyde & 35.05 & 39.12 & Cuminaldehyde & 35.33 \\
\hline 39.54 & $\gamma$-Terpinene-7-al & 13.41 & 39.53 & $\gamma$-Terpinene-7-al & 13.04 & 39.53 & $\gamma$-Terpinene-7-al & 13.22 \\
\hline 40.20 & Anethole & 3.98 & 40.19 & Anethole & 8.56 & 40.19 & Anethole & 6.27 \\
\hline 45.21 & Carotol & 0.51 & 45.21 & Carotol & 0.45 & 45.21 & Carotol & 0.48 \\
\hline 46.84 & Cumin alcohol & 0.46 & 46.84 & Cumin alcohol & 0.45 & 46.84 & Cumin alcohol & 0.45 \\
\hline 49.26 & Carvacrol & 0.50 & 49.26 & Carvacrol & 0.47 & 49.26 & Carvacrol & 0.48 \\
\hline \multicolumn{2}{|c|}{ Unidentified } & & \multicolumn{2}{|l|}{0.41} & & \multicolumn{2}{|l|}{0.65} & 0.61 \\
\hline \multicolumn{2}{|c|}{ Total } & & \multicolumn{3}{|l|}{99.5} & \multicolumn{2}{|l|}{99.3} & 99.3 \\
\hline
\end{tabular}

Many previous scientific studies have shown that besides agronomic applications, genetic and environmental factors were effective on the chemical composition of essential oil of medicinal and aromatic plants [8, 9, 10]. The results obtained from this study showed us that row space change, which was an important agronomic application in medicinal aromatic plant cultivation, had an effect on the essential oil composition. The difference in the values of the anise essential oil components obtained from the study compared to the composition determined in the previous studies can be explained by the genetic differences of the plant materials used in the studies and the climatic differences of the regions where the studies were conducted $[1,3,5]$. The difference between this study and previous studies, especially in terms of the main component values of essential oil, can be explained by the difference in chemotype of the plant materials used in the studies.

\section{Conclusions and discussion}

According to result of this research; mean of the two-years, the highest seed yield $\left(0.79 \mathrm{t} \mathrm{ha}^{-1}\right)$ was determined in $30 \mathrm{~cm}$ row spacing and highest essential oil yield $\left(21.08 \mathrm{~L} \mathrm{ha}^{-1}\right)$ was obtained from the $20 \mathrm{~cm}$ row spacing application. Although there was no statistically significant difference between the 20 and $30 \mathrm{~cm}$ row spacing in terms of seed yield and essential oil yield; It may be recommended to sow in $30 \mathrm{~cm}$ row spacing for seed production and in 20 $\mathrm{cm}$ row spacing for essential oil production under Eskisehir ecological conditions. However, considering the fact that the yield of $0.49 \mathrm{~L} \mathrm{ha}^{-1}$ lower essential oil was obtained in the $30 \mathrm{~cm}$ row spacing compared to the $20 \mathrm{~cm}$ row spacing and that these two values were statistically in the same group, sowing with $30 \mathrm{~cm}$ row spacing may be recommended for both production purposes. 


\section{References}

[1] Albulushi, S.M.A., Al Saidi, H., Amaresh, N. and Mullaicharam, A.R. (2014). Study of physicochemical properties, antibacterial and gc-ms analysis of essential oil of the Aniseed (Pimpinella anisum Linn.) in Oman. Research and Reviews: Journal of Pharmacognosy and Phytochemistry, 2(4), 24-33.

[2] Karac, T. and Efe, L. (2017). Pharmacological properties of anise (Pimpinella anisum L.) plant and its use for therapeutic purposes. 12. Field Crops Congress, Proceeding Electronic Book, Kahramanmaras, Turkey. pp: 354, poster. (in Turkish)

[3] Salim, E.A., Yagi S. and Elyass H.M.M. (2016). Histology, phytochemistry and bacterial activity of anise (Pimpinella anisum L.) seed and essential oil. J. Bacteriol Mycol Open Access, 3(4), doi:10.15406/jbmoa.2016.03.

[4] Hassan, O.M. and Elhassan, I.A. (2017). Characterization of essential oils from fruits of Umbelliferous crop cultivated in Sudan I. Pimpinella anisum L (Anise) and Anethum graveolens L. (Dill). Journal of Pharmacognosy and Phytochemistry, 6(1), 109-112.

[5] Shojaii, A. and Fard, M.A. (2012). Review of pharmacological properties and chemical constituents of Pimpinella anisum. International Scholarly Research Network ISRN Pharmaceutics ID 510795 p:1-8. doi:10.5402/2012/510795.

[6] Khalid, A.K. (2015). Quality and quantity of Pimpinella anisum L. essential oil treated with macro and micronutrients under desert conditions. International Food Research Journal, 22(6), 2396-2402.

[7] Dutta, S., Munda, S., Devi, N. and Lal, M. (2018). Compositional variability in leaves and inflorescence essential oils of Cymbopogon khasianus (Hack.) stapf ex bor collected from meghalaya: A Biodiversity hotspot. Journal of Essential Oil Bearing Plants, 21(3), 640-657. doi: 10.1080/0972060X.2018.1486233.

[8] Benbelaid, F., Abdouna, M.A., Khadir, A. and Bendahou, M. (2013). Drying effect on yield and antimicrobial activity of essential oils. Int. J. Med. Arom. Plants, 3(1), 93-101.

[9] Nurzyńska-Wierdak, R, Bogucka-Kocka, A. and Szymczak, G. (2014). Volatile constituents of Melissa officinalis L. leaves depending on plant age. Nat. Prod. Comm., 9(5), 703-706.

[10] Aćimović, M.G., Dolijanović, Ž.K., Oljača, S.I., Kovačević, D.D. and Oljača, M.V. (2015). Effect of organic and mineral fertilizers on essential oil content in caraway, anise and coriander fruits. Acta Sci. Pol. Hortorum Cultus, 14(1), 95-103.

[11] Arslan, N., Gurbuz, B. and Gumuscu, A. (1999). A Research On Yield And Yield Components Of Different Originated Anise ( Pimpinella anisum L.). Journal of Field Crops Central Research Institute, 8, 1-2. (in Turkish)

[12] Stainier, C. (1975). Role and functions of the European Pharmacopoeia. Ann Ist Super Sanita, 11(3-4), 211-219.

[13] Baloch, M.S., Shah, I.T.H., Nadim, M.A., Khan, M.I. and Khakwani, A.A. (2010). Effect of seeding density and planting time on growth and yield attributes of wheat. The Journal of Animal \& Plant Sciences, 20(4), 239-240.

[14] Kara, N., Katar, D. and Baydar, H. (2015). Yield and quality of black cumin (Nigella sativa L.) populations: The effect of ecological conditions, Turk J. Field Crops, 20(1), 9-14. doi: 10.17557/.23190.

[15] Bieńkowski, T., Żuk-Gołaszewska, K., Kurowski, T. and Gołaszewski, J. (2016). Agrotechnical indicators for Trigonella foenum-Gracum L. production in the environmental conditions of Northeastern Europe. Turk J. Field Crops, 21(1), 16-28. doi: 10.17557/tjfc.37573.

[16] Katar, N., Katar, D., Temel, R., Karakurt, S., Bolatkıran, İ., Yıldız, E. and Soltanbeigi, A. (2019). The effect of different harvest dates on the yield and quality properties of rosemary Rosmarinus officinalis L. plant. Biological Diversity and Conservation, 12(3), 7-13. doi: 10.5505/biodicon.2019.29292.

[17] Goksoy, A.T., Sincik, M., Erdogmus, M., Ergin, M., Aytac, S., Gumuscu, G., Gunduz, O., Keles, R., Bayram, G. and Senyigit, E. (2019). The parametric and non-parametric stability analyses for interpreting genotype by environment interaction of some soybean genotypes. Turk J. Field Crops, 24(1), 28-38. doi:10.17 $557 /$ tjfc. 562637.

[18] Sonmez, C. (2019). Effect of different harvest times on some yield and essential oil characteristics in Origanum onites L. Turk J. Field Crops, 24(1), 106-110. doi: 10.17557/tjfc.571844.

[19] Kevseroglu, K. (2014). Plant Ecology Textbook. Samsun, Turkey. Ondokuz Mayis University, Faculty of Agriculture Publications Samsun. (in Turkish).

[20] Antal, T., Kerekes, B. and Sikoly, L. (2012). Effect of vacum freeze-drying on quality of lemon balm leaves (Melissa officinalis L.). Analele Universităţii din Oradea, Fascicula Protecţia Mediului, 19, 1-10. 
[21] Aydın, D. and Katar, D. (2016). Effects of Different Row Spacings on The Yield and Quality in Different Coriander (Coriandrum sativum L.) Cultivars. III. Medicinal and Aromatic Plants Symposium, Antalya, Turkey. S: 66-74. (In Turkish)

[22] Turhan, H. 2006. Lemon balm (Chapter 23, p:390-399). in K.V. Peter (ed.) Handbook of herbs and spices. Volume 3. Woodhead Publishing ISBN-10: 1-84569-171-7 (e-book). Woodhead Publishing Limited Cambridge, England.

[23] El Rasheed, A.S., Abu-Bakr, A.A.G., Hassan, E.K. and Gaffar, M.E. (2016). Evaporation of Spearmint (Mentha spicata var. viridis L.) herb oil during one year of storage under semi-arid condition. Agri Res \& Tech: Open Access Journal, 2(4), 555-594. doi: 10.19080/ARTOAJ.2016.02.555594.

[24] Shahhoseini, R, Azizi, M., Asili, J., Moshtaghi, N. and Samiei, L. (2019). Comprehensive assessment of phytochemical potential of Tanacetum parthenium (L.) Phenolic compounds, antioxidant activity, essential oil and parthenolide. Journal of Essential Oil Bearing Plants, 22(3), 614-629. doi:10.1080/0972060X.2019.1 632228.

[25] Hasimi, N., Tolan, V., Kizil, S. and Kilinc, E. (2014). Determination of Essential Oil Composition, Antimicrobial and Antioxidant Properties of Anise (Pimpinella anisum L.) and Cumin (Cuminum cyminum L.) Seeds. Journal of Agricultural Sciences, 20, 19-26. (in Turkish)

[26] Kara, N. (2015). Yield, quality, and growing degree days of Anise (Pimpinella anisum L.) under different agronomic practices. Turk J. Agric. For., 39, doi:10.3906/tar-1411-143. 